\title{
Observação de diferentes graus de lesões em estômagos e úlcera gástrica em leitões de creche. Isolamento de Arcobacter cryaerophilus
}

\author{
Observation of different degrees of lesions in stomachs and gastric ulcer \\ in pigs in the nursery. Isolation of Arcobacter cryaerophilus \\ Sérgio J osé de Oliveira ${ }^{1}$, Roberto Tesi Bernardi ${ }^{1}$,Vanessa Daniele Mottin ${ }^{1}$, \\ Diego Hepp ${ }^{2} \&$ Daniel Thompsen Passos ${ }^{2}$
}

\begin{abstract}
RESUMO
A úlcera gástrica (UG) é uma doença multifatorial, sendo uma das principais causas de morte súbita e esporádica de reprodutores. No suíno, as lesões de UG são localizadas na pars oesophagea do estômago, na qual o epitélio não é glandular. As causas das lesões estomacais são múltiplas, não havendo, até o momento, confirmação de envolvimento de bactérias na etiologia. O presente trabalho teve por objetivos verificar os graus de UG em estômagos de leitões em idade de creche, abatidos em um matadouro do Rio Grande do Sul, Brasil, bem como detectar a presença de bactérias do gênero Arcobacter. Foram examinados 80 estômagos de leitões em idade de creche, com peso médio de $14,6 \mathrm{~kg}$, abatidos em um frigorífico no Rio Grande do Sul. O exame macroscópico revelou 57 (71,3\%) sem lesão, 20 (25\%) com lesão de paraqueratose na região esofageana (grau 1), e 3 estômagos apresentando, respectivamente, graus 2,3 e 4, com erosões e ulcerações. Foi isolado Arcobacter cryaerophilus de uma amostra de lesão de grau 1, sendo este o primeiro relato sobre a presença destas bactérias em estômago de leitão. São alertados os suinocultores para que se analisem as causas de úlcera gástrica cedo na creche, visando a prevenir perdas na recria e terminação.
\end{abstract}

Descritores: estômago, leitões, úlcera gástrica, Arcobacter cryaerophilus.

\begin{abstract}
Gastric ulcer (GU) is a multifactorial disease, being one of the most important causes of death of adult pigs. Lesions of GU in pigs are seen in pars oesophagea of the stomach which is non glandular. The causes of the lesions are variable and until now there is not confirmation on the involvement of bacteria in the aetiology. The present work had as objective verify the degrees of UG in stomachs of piglets on nursery age, slaughtered at an abattoir in Rio Grande do Sul, Brazil, detecting the presence of Arcobacter spp. Eighty stomachs of piglets slaughtered at nursery age, mean weight $14.6 \mathrm{~kg}$, were examined in an abattoir in the State of Rio Grande do Sul, Brazil. No lesions were detected into 57 (71.3\%), whereas 20 (25\%) showed hypercheratosis in the pars oesophagea (score 1) and three presented respectively scores 2, 3 and 4 (erosions and ulcerations). It was isolated Arcobacter cryaerophilus from one sample (lesion score 1). This is the first report on the presence of Arcobacter sp. from stomachs of piglets. It is an alert to pig farmers in order to look for the causes of GU early in the nursery, to prevent losses on growing or fattening pigs.
\end{abstract}

Keywords: stomachs, piglets, gastric ulcer, Arcobacter cryaerophilus. 


\section{INTRODUÇÃo}

A úlcera gástrica (UG) é uma doença multifatorial, sendo mais frequente em suínos criados intensivamente em confinamento e é uma das principais causas de morte súbita e esporádica de reprodutores [14]. As causas das lesões estomacais são múltiplas, ligadas a fatores ambientais, de manejo, nutricionais e estressantes, entre outras, conforme revisão de Almeida et al. [1]. Suínos que consomem ração com granulometria fina (abaixo de $500 \mu \mathrm{m}$ ) estão mais propensos a apresentar lesões na pars oesophagea. Por outro lado, a interrupção da alimentação (o jejum) tem sido causa de lesões ulcerativas [4]. Fatores genéticos também predispõem para ulceração na região esofágica do estômago em suínos [12]. Em seres humanos, foi comprovado que infecção por Helicobacter pylori está relacionada com a ocorrência de úlcera gástrica [11].

No suíno, as lesões de UG são localizadas no quadrilátero esofágico do estômago, na qual o epitélio não é glandular. As lesões são classificadas em graus, conforme a intensidade, iniciando com paraqueratose e seguindo com erosões até ulcerações. Em suínos, ainda não está comprovada a importância de bactérias no desenvolvimento de úlcera gástrica esofágica.

Através do presente trabalho, foram examinados 80 estômagos de leitões de creche com vistas à observação de lesões de UG e presença de bactérias do gênero Arcobacter. Estas bactérias foram isoladas de fetos suínos abortados no Rio Grande do Sul [8], de carne de frangos e de suínos [9,10], e provocam enterite em seres humanos [3,6,17]. Arcobacter spp. foram detectadas em estômagos de suínos de abate, por PCR, em uma pesquisa nos Estados Unidos [16].

\section{MATERIAIS E MÉTODOS}

\section{Exames macroscópicos em estômagos}

Foram examinados 80 estômagos de leitões em idade de creche abatidos em um frigorífico no Rio Grande do Sul, pertencentes a três lotes, visando à observação de lesões na região esofagiana. Os estômagos eram cortados na curvatura maior e retirado o conteúdo, observando-se a pars oesophagea, classificando nos diferentes graus, segundo Sobestiansky et al. [13], desde zero (sem lesão), 1 (paraqueratose), 2 (paraqueratose e ulceração menor do que 33\%), 3 (paraqueratose e ulceração até 66\%) e 4 (paraqueratose e ulceração acima de $66 \%$ ).

\section{Colheita dos materiais}

Foram colhidas amostras da região esofágica (não glandular) do estômago dos suínos examinados. Era colhido um fragmento de lesão, sendo inoculado em meio de cultura líquido de $\mathrm{EMJH}^{1}$ (Ellinghausen MacCullough Johnson and Harris) em tubos, para cada amostra. Foram igualmente examinadas amostras colhidas de estômagos sem lesões de úlcera gástrica. Os materiais eram transportados ao Laboratório.

\section{Exames laboratoriais}

No laboratório, os tubos eram incubados a $25^{\circ} \mathrm{C}$, até 5 dias, e as culturas eram examinadas em microscópio com condensador de campo escuro, para que fossem observados micro-organismos com a forma e a motilidade de Arcobacter spp. Os cultivos em meio líquido eram então filtrados através de membrana de celulose acetato de $0,45 \mu \mathrm{m}$ sobre a superfície de meio sólido de Agar Sangue [15]. As placas permaneceram durante 60 minutos no ambiente e após foram retiradas as membranas filtrantes e o inóculo foi espalhado com alça no meio de cultura, sendo, então, incubadas de 25 a $30^{\circ} \mathrm{C}$, em aerobiose, por 48 horas. Colônias típicas eram analisadas por coloração das bactérias pelo método de Gram, era realizado o teste de catalase e eram inoculadas em caldo $\mathrm{BHI}^{2}$ (Brain Heart Infusion) em tubos, para obtenção de cultivos puros de Arcobacter spp.

\section{Testes moleculares}

Foi amplificado um fragmento de 470 pares de bases (pb) do gene 16S do RNA ribossomal do genoma de bactérias do gênero Arcobacter, utilizando-se a técnica de PCR com primers ARC3F e ARC4R, após a extração do DNA pela técnica de sílica [2]. A diferenciação entre as espécies Arcobacter cryaero-philus e Arcobacter butzleri foi realizada pela clivagem do fragmento amplificado, utilizando-se a enzima de restrição $S s p 1$. Observa-se a formação dos fragmentos 420 e $50 \mathrm{pb}$ para $A$. butzleri e a presença do fragmento intacto de $470 \mathrm{pb}$ para A. cryaerophilus.

\section{RESULTADOS}

Foram abatidos 3 lotes, respectivamente, de 27, 28 e 25 leitões de creche, no total de 80 . Os exames de estômagos revelaram 57 sem lesão, 20 com lesão de grau um, $1 \mathrm{com}$ grau dois, $1 \mathrm{com}$ grau três e $1 \mathrm{com}$ grau quatro. A média de peso dos lotes foi, respectivamente, de $14,3 \mathrm{~kg}, 17,2 \mathrm{~kg}$ e 12,9 kg. Resultados constam na Tabela 1 e na Figura 1. Foi isolado Arcobacter sp. de 
uma amostra de lesão grau 1 do lote 02 , sendo positivo em prova de catalase e classificado por prova de PCR como sendo Arcobacter cryaerophilus.

\section{DISCUSSÃO}

Predominaram estômagos sem lesão $(71,3 \%)$, seguindo-se lesões de paraqueratose em $25 \%$ dos estômagos. Erosões e ulcerações graves, como se observa na Figura 1, ocorreram em dois leitões, respectivamente, grau 3 e 4 . Este tipo de lesão seria esperado em suínos de recria e terminação, de 3 a 6 meses de idade e em animais adultos, conforme tem sido observado [4]. Por outro lado, não é possível conhecer a prevalência de lesões ulcerativas em estômagos de leitões de creche, em vista do pequeno número de abates, sendo os estudos dirigidos principalmente a suínos em idade de abate, isto é, terminados devido às perdas que ocorrem nas granjas (monitoria em frigorífico).

No entanto, Healy et al. [5] alimentaram leitões de creche em dois grupos, respectivamente, recebendo milho moído com granulometria de $300 \mu \mathrm{m}$ e $900 \mu \mathrm{m}$ e observaram a ocorrência de 3 casos de úlcera gástrica e 3 de erosões em leitões alimentados com milho de granulometria mais fina. Isto indica que a granulometria da ração pode influir na ocorrência de lesões no estômago, bem cedo, em período de creche. Este fator pode ter maior influência caso ocorram concomitantemente fatores estressantes como superlotação, brigas, frio, ocorrência de doenças infecciosas que interrompam o consumo de ração. No caso dos leitões examinados no presente trabalho, não foi possível realizar um estudo nas granjas de origem. Observa-se, na Tabela 1, que 25\% dos estômagos apresentaram hiperqueratose, que é precursora da úlcera esofagogástrica. Há, portanto, a possibilidade de que, nas fases de recria e terminação, estes suínos, ou alguns deles,

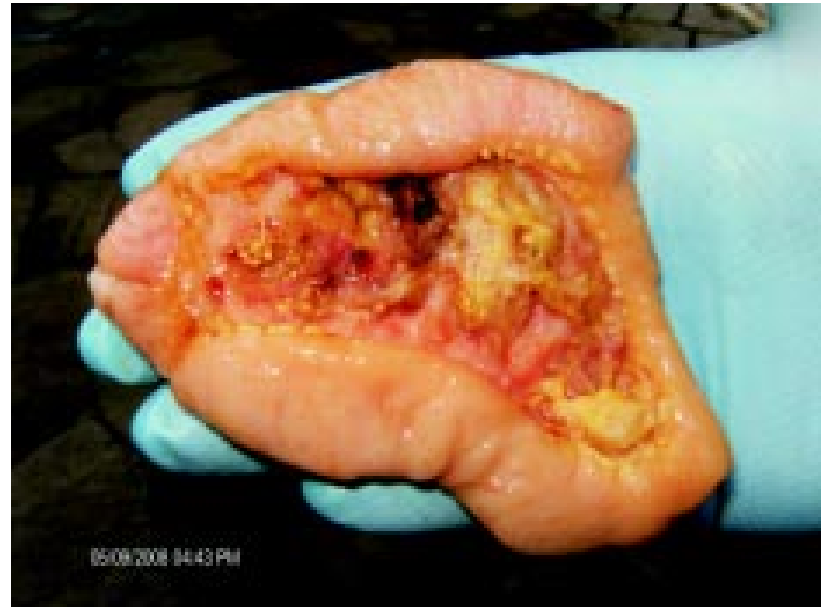

Figura 1. Ulcerações e paraqueratose em estômago de leitão em idade de creche, abatido em um frigorífico no Rio Grande do Sul.

pudessem desenvolver erosões e ulcerações. Considerando-se apenas as lesões de hiperqueratose com engrossamento do epitélio, estas seriam suficientes para estabelecer atraso no desenvolvimento dos suínos, pois geram dificuldade para os nutrientes atingirem as células, segundo Almeida et al. [1]. Portanto, a constatação de lesões na pars oesophagea do estômago de leitões em três lotes examinados no presente trabalho, serve de alerta aos suinocultores, para que seja feita a prevenção da ocorrência de úlceras gástricas ou as formas mais leves de lesões que provocam atraso no ganho de peso. Esta prevenção seria realizada através da análise e correção de fatores desencadeantes, já bem cedo, em leitões em idade de creche.

Foi isolado Arcobacter sp de uma amostra de lesão grau 1 do lote 02 , sendo positivo em prova de catalase e classificado por prova de PCR como sendo A. cryaerophilus. Até o momento, não consta na bibliografia informação sobre isolamento de Arcobacter sp de estômago de leitão, sendo este o primeiro relato. Suarez et al. [16] detectaram a presença de Arcobacter em estômago de suínos de abate,

Tabela 1. Resultado de exames macroscópicos em estômagos de leitões em idade de creche abatidos em um frigorífico no Rio Grande do Sul.

\begin{tabular}{|c|c|c|c|c|c|c|c|}
\hline Lotes & $\mathrm{N}^{o}$ de suínos & Peso médio ${ }^{1}(k g)$ & Sem lesão & Lesão Grau 1 & Lesão Grau 2 & Lesão Grau 3 & Lesão Grau 4 \\
\hline 01 & 27 & 14,3 & 20 & 06 & 01 & - & - \\
\hline 02 & 28 & 17,2 & 22 & 05 & - & - & 01 \\
\hline 03 & 25 & 12,9 & 15 & 09 & - & 01 & - \\
\hline Totais & 80 & 14,8 & $57(71,3 \%)$ & $20(25 \%)$ & $01(1,25 \%)$ & $01(1,25 \%)$ & $01(1,25 \%)$ \\
\hline
\end{tabular}


portanto terminados. Os autores constataram que as bactérias estavam presentes em estômagos com e sem lesões, não sendo possível atribuir influência às mesmas na ocorrência de lesões; para tal, seria necessário novo experimento. Em suínos, ao contrário do que ocorre em seres humanos, as úlceras esofagogástricas não têm sido atribuídas a causas infecciosas [7]. No Brasil, Arcobacter sp já foram isolados de fetos suínos abortados, líquido prepucial de suínos reprodutores e músculo de carcaças $[8,10]$. As bactérias foram cultivadas de água de rios e de fezes de suínos e bovinos, sugerindo que se encontram no ambiente [18]. A presença de Arcobacter cryaerophilus em estômago de leitão, como constatado no presente trabalho, teria explicação plausível pela ingestão de água ou matérias contaminadas (do piso ou ração), mas este fato necessita ainda de comprovação, bem como alerta para que se desenvolvam novas pesquisas com o objetivo de investigar sobre o papel desempenhado por determinadas bactérias (incluindo-se Arcobacter spp), na ocorrência de úlceras gástricas em suínos.

\section{CONCLUSÕES}

Foram observadas lesões na pars oesophagea de $28,7 \%$ de estômagos de leitões em idade de creche, sendo dois casos de ulcerações.

Este achado serve como alerta para que ocorra a prevenção do desenvolvimento de úlceras gástricas em suínos de recria e terminação, através da análise das causas desencadeantes bem cedo, em leitões na creche.

Foi isolado Arcobacter cryaerophilus de amostra de lesão de paraqueratose (grau 1). Este é o primeiro relato sobre a presença das bactérias em estômago de leitão. Sugere-se, portanto, que se inclua, além do gênero Helicobacter, também o gênero Arcobacter nas investigações sobre possíveis causas infecciosas de úlcera gástrica.

Agradecimentos. Os autores agradecem à Técnica de Laboratório Jane Mendez Brasil, pelos serviços em bacteriologia.

\section{NOTAS INFORMATIVAS}

${ }^{1}$ Ellinghausen MacCullough Johnson and Harris, Difco, USA. ${ }^{2}$ Brain Heart Infusion, Difco, USA.

\section{REFERÊNCIAS}

1 Almeida M.N., Vearick G., Lippke R.T., Lagemann F. L., Correa A.M.R. \& Barcellos D.E.S.N. 2006. Úlceras gástricas em suínos. A Hora Veterinária, 153: 62-66.

2 Boom R., Sol C.J.A. \& Salimans M.M.M. 1990. Rapid and simple method for purification of nucleic acids. Journal of Clinical Microbiolog. 28: 495-503.

3 Fernandez H., Krause S. \& Villanueva M.P. 2004. Arcobacter butzleri an emerging enteropathogen: communication of two cases with chronic diarrhea. Brazilian Journal of Microbiology. 35: 216-218.

4 Friendship R. 1999. Gastric ulcers. In: Straw B.E., Dallaire S., Mengeling L. \& Taylor D.J. (Eds). Diseases of swine. Ames: Iowa State University Press, p. 685-694.

5 Healy B.J., Hanckok J.D. \& Kenedy G.A. 1994. Optimum particle size of corn and hard and soft sorghum for nursery pigs. Journal of Animal Science. 72: 2227-2236.

6 Lauwers S., Breynaert J. \& Van Etterijk H. 1996. Arcobacter butzleri in the elderly in Belgium. In: D.G. Newell, J.M. Ketley J.M. \& R.A. Feldman (Eds). Campylobacters, Helicobacters and related organisms. New York: Plenum Press, p.515-517.

7 Melnichouk S.I. 2002. Mortality associated with gastric ulceration in swine. Canadian Veterinary Journal. 43: 223-225.

8 Oliveira S.J., Baetz A.L., Wesley I.V. \& Harmon K.M. 1997. Classification of Arcobacter species isolated from aborted pig fetuses and sows with reproductive problems in Brazil. Veterinary Microbiology. 57: 347-354.

9 Oliveira S.J., Moraes H.L.S., Kuchenbecker B.S. \& Ikuta N. 2001. Isolation of Arcobacter spp. from poultry carcasses, in Brazil. Ciência Rural. 31: 639-643.

10 Oliveira S.J., Ikuta N., Lunge V.R., Fonseca A. \& Moraes H.L.S. 2003. Isolamento de Arcobacter butzleri de músculos de carcaças de suínos de terminação e de matrizes descartadas abatidos em um matadouro no Estado do Rio Grande do Sul, Brasil. Ciência Rural. 33: 889-892.

11 Queiroz D.M.M., Rocha G.A. \& Mendes E.N. 1996. Association between Helicobacter and gastric ulcer disease of the pars oesophagea in swine. Gastrenterology. 111: 19-27.

12 Sobestiansky J., Barcellos D.E.S.N., Mores N., Oliveira S.J. \& Carvalho L.F. 1999. Clínica e Patologia Suína. 2.ed. Goiânia: Art 3 Impressos Especiais, 463 p. 
13 Sobestiansky J., Matos M.P.C. \& Souza C.M. 2001. Monitoria patológica de suínos em matadouro.52 p

14 Sobestiansky J. \& Barcellos D.E.S.N. 2007. Doenças de Suínos. Goiânia: Cânone Editorial, 767p.

15 Steele T.W. \& MCDermott S.N. 1984. Technical note: the use of membrane filters applied directly to the surface of agar plates for the isolation of Campylobacter jejuni from feces. Pathology. 15: 263-265.

16 Suarez D.L., Wesley I.V. \& Larson D.J. 1997. Detection of Arcobacter species in gastric samples from swine. Veterinary Microbiology. 57: 325-336.

17 Vandenberg O. Dediste A., Houf K. \& Ibeckwen S. 2004. Arcobacter species in humans. Emerging Infectious Diseases. 10: $1863-1867$.

18 Wesley I.V. 1996. Helicobacter and Arcobacter species: risks for foods and beverages. Journal of Food Protection. 59: 1127-1132. 